Michą NoWICKI

ORCID 0000-0001-6147-9295

Uniwersytet im. Adama Mickiewicza

$w$ Poznaniu

\title{
WARTOŚĆ WYCHOWANIA W RODZINIE LUTERAŃSKIEJ W PIŚMIENNICTWIE STAROPOLSKIM XVI I XVII WIEKU
}

\begin{abstract}
Nowicki Michał, Wartość wychowania w rodzinie luterańskiej w piśmiennictwie staropolskim XVI $i$ XVII wieku [The Value of Upbringing in the Lutheran Family in the Old Polish Literature of the 16th and 17th Centuries]. Studia Edukacyjne nr 54, 2019, Poznań 2019, pp. 103-122. Adam Mickiewicz University Press. ISSN 1233-6688. DOI: 10.14746/ se.2019.54.7
\end{abstract}

The article deals with the issue of the value of upbringing in the Lutheran family as shown in the Old Polish literature of the 16th and 17th centuries. The first of the two parts discusses the formation of Lutheran educational thought in the context of the development of modern culture, reforms of Martin Luther and the work of Philip Melanchthon. The second part demonstrates the reception of these views in Polish pedagogical texts.

In these texts, several features specific to the Protestant perspective can be distinguished. First of all, it is a strongly emphasized fear of God, a significant role of the father in the upbringing of not only children but also the whole family together with the retinue (following the example of the Roman tradition), and a rather poorly emphasized woman's role in the family (only in the context of her maternal function in the period of necessary care for children). Particular importance was attached to the family itself as an institution established by God, to parenthood and the need to carefully educate offspring, to the personal involvement and efforts of both parents to educate their children.

Key words: history of education, modern history, family, Lutherans

Renesans europejski w sposób szczególny zapisał się w historii wychowania, zarówno w zakresie praktyki edukacyjnej, jak i teorii. Epoka poprzednia oczywiście także interesowała się teorią wychowania, ale najczęściej adresowana była ona do elit społecznych. Wychowanie powszechne ograniczało się w zasadzie do kaznodziejstwa albo teologii. Ta znowu jednak mogła być wykorzystana tylko przez elity intelektualne. Upowszechnienie oświaty śred- 
niej oraz tekstów drukowanych w XVI wieku przyczyniło się niewątpliwie do zwiększenia recepcji myśli pedagogicznej w społeczeństwie.

Przyglądając się luterańskim tekstom pedagogicznym z XVI wieku, łatwo zauważyć, że bardzo silnie są one osadzone w antycznej, zwłaszcza chrześcijańskiej, tradycji pedagogicznej. Trudno zresztą wyobrazić sobie, by chrześcijańscy wszak pisarze odcinali się od wzorca rodziny i wychowania, prezentowanego w tradycji biblijnej, skoro to właśnie Biblia była dla nich największym autorytetem. Jest to przecież powszechnie znany trend kulturowy, obecny także w europejskiej myśli pedagogicznej. Dobrym przykładem będzie Giovanni Pico della Mirandola, Erazm z Rotterdamu, czy Jan Ludwik Vives, którzy postulowali powrót do antycznych korzeni i ścisłe powiązanie teorii pedagogicznej z tekstami biblijnymi, a także realizowanie nowego celu wychowawczego, określanego jako paideia Christi ${ }^{1}$.

Z jednej strony widzimy więc wysoką pozycję i ważną wychowawczo rolę ojca, obecną w tradycji żydowskiej, z drugiej - nowotestamentowy wzorzec świętej rodziny ${ }^{2}$. Podobnie jak w całym ruchu humanistycznym, zauważalna jest też i tutaj swoista fascynacja poglądami Pseudo-Plutarcha, Kwintyliana, Cycerona, czy Seneki, z których pisarze luterańscy czerpali bardzo chętnie i bez skrępowania (przykładem chociażby kwestie karmienia piersią zapożyczone przez Erazma Glicznera od Pseudo-Plutarcha). Nie zapominajmy, że treści pedagogiczne to nie tylko wspomniani teoretycy. Dla propagowania wzorca rodziny wielkie zasługi położyli też Wergiliusz, przedstawiając wzorowe zachowanie Eneasza, jako ojca, Pliniusz Młodszy wychwalający wzajemne uczucia małżeńskie, czy Kato Starszy osobiście wychowujący i piszący nawet podręczniki dla syna ${ }^{3}$. Jeśli weźmiemy pod uwagę fakt, że w szkołach humanistycznych autorzy ci byli powszechnie "obecni”, to oczywiste się stanie, że wzorce rodziny przez nich reprezentowane musiały odpowiednio silnie oddziaływać na uczniów i mieć wpływ na ich późniejsze życie. Jerzy Axer podkreślał zresztą, że w Polsce wykształcił się specyficzny typ recepcji wszystkich najważniejszych autorów łacińskich ${ }^{4}$.

Antyczne wzorce wychowania chrześcijańskiego w czasach średniowiecznych konfrontowane były z wzorcami monastycznymi, zalecającymi ascezę,

\footnotetext{
${ }^{1}$ J. Budzyński, Paideia humanistyczna, czyli wychowanie do kultury. Studium z dziejów klasycznej edukacjiw gimnazjach XVI-XVIII wieku (na przykładzie Śląska), Częstochowa 2003, s. 41.

2 Zob. J. Śledzianowski, Autorytet rodzicielski w Rodzinie Nazaretańskiej i dzisiaj, Paedagogia Christiana, 2011, 27, 1. Por. E. Sakowicz, Wychowanie młodego pokolenia w religii biblijnego Izraela, Paedagogia Christiana, 2011, 27, 1, s. 25-47.

3 Więcej na ten temat, zob. A. Stefańczyk, Pater familias, Człowiek w Kulturze, 2012, 22, s. 207-227.

${ }^{4}$ J. Axer, Kultura polska z punktu widzenia mechanizmów recepcji tradycji antycznej. Prolegomena do syntezy, [w:] Humanistyczne modele kultury nowożytnej wobec dziedzictwa starożytnego, red. M. Prejs, Warszawa 2010, s. 57.
} 
zwłaszcza w zakresie wstrzemięźliwości płciowej (chociaż trzeba pamiętać, że deprecjonowanie ciała, chociaż powszechne w średniowieczu, spotykało się z głosami krytyki, także wśród Ojców Kościoła $\left.{ }^{5}\right)$. Średniowiecze doprowadziło też do specyficznego zaniku ojca na scenie wychowawczej, który wówczas pojawiał się tylko epizodycznie, zwłaszcza w traktatach pedagogicznych przeznaczonych dla przedstawicieli elity społecznej ${ }^{6}$.

Sytuacja zaczęła się zmieniać w okresie renesansu. I chociaż wczesnorenesansowa teoria pedagogiczna koncentrowała się jeszcze na wybitnych jednostkach i miała raczej jednostkowych odbiorców, to z czasem pojawiły się traktaty takiej rangi, jak De disciplinis tradendis Jana Ludwika Vivesa, czy utopijne rozważania Tomasza Morusa, które cieszyły się ogromną popularnością. Jednym z ważniejszych powodów tego było z pewnością „odkrycie dziecka” $\mathrm{w}$ tej epoce ${ }^{7}$. Stopniowo też, dzięki rosnącej popularności pedagogiki, teoria zaczęła być adresowana powszechniej także do „zwykłych” ludzi, a nie tylko najbardziej prominentnych osobistości. Zaowocowało to zainteresowaniem społecznym teorią wychowawczą, co w Polsce objawiło się w praktyce tworzenia tak zwanych instrukcji rodzicielskich ${ }^{8}$.

Warto w tym miejscu zwrócić uwage na ogromną zasługę reformacji w rozwoju europejskiej pedagogiki. Zakładając potrzebę osobistej lektury Pisma Świętego i powszechnego dostępu do podstaw wiary, a także propagując model religijności osobistej ${ }^{9}$, pojawiła się konieczność odpowiedniego przygotowania intelektualnego wiernych do tego zadania. $Z$ jednej więc strony trzeba było zachęcić ich do edukacji, z drugiej natomiast udostępnić im odpowiednią literaturę w języku narodowym. Dotyczyło to także kwestii wychowawczych. Pamiętać trzeba, że katolicka Europa posiadała solidne za-

${ }^{5}$ W. Turek, Godność ciała ludzkiego wedtug Tertuliana. Analiza komentarzy do tekstów Rdz 1, 26-27; 2, 8; 1Kor 3, 16, Vox Patrum, 2015, 63, 35, s. 63-75.

${ }^{6}$ Historia ojców i ojcostwa, red. J. Delumeau, D. Roche, przekł. J. Radożycki, M. Radożycka-Paoletti, Warszawa 1995, s. 56 i n.

7 J. Delumeau, Cywilizacja Odrodzenia, Warszawa 1987, s. 317.

${ }^{8}$ D. Żołądź-Strzelczyk, "Pod każdym względem szlachetne ci daję wychowanie”. Studia z dziejów wychowania szlachty w epoce staropolskiej, Wrocław 2017; taż, Ojcowskie synom przestrogi. Instrukcje rodzicielskie (XVI-XVII w.), oprac, i wstępem opatrzyły D. Żołądź-Strzelczyk, M.E. Kowalczyk, Wrocław 2017; taż, Przestrogi i nauki dla dzieci. Instrukcje rodzicielskie (XVIII w.), oprac, i wstępem opatrzyły M.E. Kowalczyk, D. Żołądź-Strzelczyk, Wrocław 2017; H. Barycz, Andrzej Maksymilian Fredro wobec zagadnień wychowawczych, Archiwum do Dziejów Oświaty i Wychowania, 1948, 6; W. Kaczorowski, Wychowanie Janusza Radziwiłła w świetle instrukcji rodzicielskiej, Sprawozdania. Opolskie Towarzystwo Przyjaciół Nauk, Wydział I Nauk Historyczno-Społecznych, 1984, 19; W. Sokołowski, Studia i peregrynacje Janusza i Krzysztofa Radziwiłtów w latach 1595-1603 (Model edukacji syna magnackiego na przełomie XVI i XVII wieku), Rozprawy z Dziejów Oświaty, 1992, 35, s. 3-35.

9 Zob. B. Milerski, Pedagogiczne dziedzictwo protestantyzmu, Gdański Rocznik Ewangelicki 2012, 6, s. 193; por. K. Meller, Luterańskie novum w kulturze polskiej XVI w., [w:] Luteranizm w kulturze pierwszej Rzeczypospolitej, red. K. Meller, Warszawa 2017, s. 13 i n. 
plecze teoretyczne $\mathrm{w}$ księgach łacińskich, luteranie natomiast, konstytuujący się dopiero, odczuwali potrzebę tworzenia nowych tekstów, zgodnych z duchem swojego wyznania, a więc dostępnych ogółowi, a nie tylko nielicznym, solidnie wykształconym jednostkom. Doskonałym przykładem takiej działalności jest spuścizna wydawnicza Jana Seklucjana, który dostarczył Polakom potrzebnej literatury ${ }^{10}$.

Początek znacznego dowartościowania znaczenia rodziny wiążemy z osobą Marcina Lutra, który zrywając z katolickim przywiązaniem do ascetyzmu i życia monastycznego, właśnie w rodzinie znalazł najlepszy sposób na praktykowanie pobożności ${ }^{11}$. W Dużym Katechizmie pisał mianowicie, że pobożne, zgodne z czwartym przykazaniem, życie rodzinne, jest lepszym gwarantem zbawienia, niż „cała świętość kartuzów, choćby się zapościli na śmierć i bez przestanku wznosili modły na kolanach"12. Luter uznał rodziców za osoby stojące na miejscu Boga, przez co należy się im od dzieci nie tylko miłość, ale także cześć. Stąd też, bez względu na charakter, sposób bycia, czy jakiekolwiek ułomności rodziców, podopieczni winni całkowicie oddawać się ich woli, gdyż jest to zgodne z wolą bożą. Luter tłumaczył, że w pojęciu czci ukrywa się, obok miłości, także karność, pokora i bojaźń, "jakby przed jakimś ukrytym majestatem" ${ }^{13}$, natomiast postępowanie zgodne z czwartym przykazaniem przyczyniłoby się do pomnożenia radości, miłości, przyjaźni i zgody, płynących przede wszystkim ze spokojnego sumienia $^{14}$. Sam Luter zresztą nie wyobrażał sobie życia poza małżeństwem, jako że to zostało ustanowione przez Boga i jest tegoż nakazem, ,"to jest cecha wrodzona natury ludzkiej"15. Jemu też zawdzięczamy nowe spojrzenie na seksualność człowieka, współżycie małżeńskie i prokreację, które stają się małżeńskim obowiązkiem. I chociaż już Augustyn podkreślał istotną rolę płodzenia dzieci przy zawieraniu małżeństw, to Luter nadaje temu problemowi nieco wyższą rangę ${ }^{16}$.

Wartości rodzinne, w świetle nauczania Marcina Lutra, powinny zostać rozciągnięte także na inne obszary życia społecznego.

${ }^{10}$ I. Warmiński, Andrzej Samuel i Jan Seklucjan, Poznań 1906, s. 170 i n.

${ }^{11}$ W 1529 r. Luter w przedmowie do dzieła Justusa Meniusa nt. chrześcijańskiego prowadzenia domu podjął się polemiki z ówczesnym zwyczajem troski o zabezpieczenie finansowe swoich dzieci, zamiast dobrego wychowania, zob. B. Milerski, O pedagogicznych pogladach Marcina Lutra, Myśl Protestancka, 1998, 1, s. 31.

${ }^{12}$ M. Luther, Mały Katechizm; Duży Katechizm, przekł. A. Wantuła, Bielsko-Biała 2000, s. 67.

13 Tamże, s. 65.

14 Tamże, s. 67.

${ }_{15}$ M. Luther, Pisma etyczne, red. M. Hintz, Bielsko-Biała 2009, s. 140.

${ }^{16}$ J. Podzielny, Cele zwiazku matżeńskiego wedtug Marcina Lutra, Roczniki Teologii Ekumenicznej, 2010, 57, 2, s. 146 i n. Augustyn z Hippony podkreślał, że ojcostwo i macierzyństwo cementują związek mężczyzny i kobiety oraz nadają mu wartość ludzką, zob. A. Swoboda, Ojcostwo Boże i ojcostwo ludzkie w ujęciu św. Augustyna, Vox Patrum 2015, 63, 35, s. 179. 
Mówiąc o czwartym przykazaniu, należy też coś powiedzieć o różnorakim posłuszeństwie wobec przełożonych, którzy mają prawo rozkazywać i rządzić. Z władzy bowiem rodziców wypływa i pochodzi wszelka inna władza. Jeżeli ojciec sam nie może wychować swego dziecka, bierze nauczyciela, który je uczy; jeżeli jest za słaby, bierze do pomocy swoich przyjaciół lub sąsiadów; jeżeli zaś umiera, przekazuje i oddaje rządy i zwierzchność innym, których się do tego wyznacza. Podobnie też musi mu być podporządkowana czeladź, parobcy i służący, aby mógł zarządzać domowym gospodarstwem. Takim sposobem wszyscy, których nazywa się zwierzchnikami, zajmują miejsce rodziców i od nich muszą wywodzić swą moc i władzę ${ }^{17}$.

Przywołany fragment pokazuje, że poglądy Marcina Lutra na rolę ojca w rodzinie osadzone są na gruncie antycznej tradycji, nadającej ojcu (pater familias) niemal nieograniczoną władzę. Z tekstów Lutra jasno wynika pierwszorzędna rola ojca w prowadzeniu rodziny i czeladzi oraz wychowywaniu całej społeczności domowej. Mały Katechizm pokazuje, że to właśnie na ojcu rodziny spoczywa obowiązek wychowywania wszystkich podopiecznych w wierze, bojaźni i to w bardzo szerokim znaczeniu. To do jego obowiązków należy tłumaczenie wszystkim domownikom zasad religijnych, w możliwie najłatwiejszy i najbardziej zrozumiały sposób ${ }^{18}$, a wreszcie pilnowanie ich przestrzegania, ale z zastrzeżeniem, by nie pobudzać swoich dzieci do gnie$\mathrm{wu}^{19}$. W tym kontekście zresztą doskonale widać inspiracje biblijne, wspólne dla całej tradycji chrześcijańskiejej ${ }^{20}$

Poglądy Marcina Lutra i innych działaczy luterańskich (zwłaszcza wysoko cenionego Filipa Melanchtona, zwanego „nauczycielem Niemiec”) bardzo szybko rozprzestrzeniły się, docierając także do Polski. Efektowi temu sprzyjała przede wszystkim renesansowa atmosfera otwartości na nowe treści, wzmożona mobilność edukacyjna, przejawiająca się na przykład w zjawisku znanym jako peregrinatio academica ${ }^{21}$. Młodzi Polacy wędrując na Zachód, odwiedzali najsławniejsze osobistości, spędzając u nich wiele czasu na dyskusjach. Do Polski natomiast docierali uczeni z Zachodu, przepojeni nowymi nurtami religijnymi, zdolni dzięki swojemu zaangażowaniu porwać dla ducha reformy sporą część społeczeństwa ${ }^{22}$. Takim przykładem może być, działający w Wielkopolsce, Krzysztof Hegendorfer, który ucząc w poznańskiej Akademii Lubrańskiego i korzystając z mecenatu rodu Górków, mógł

\footnotetext{
${ }_{17}$ M. Luther, Maty Katechizm, Duży Katechizm, s. 69.

${ }_{18}$ Tamże, s. 26, 29, 31, 34.

19 Tamże, s. 42.

${ }^{20}$ J. Kułaczkowski, Wskazania wychowawcze dla ojców w świetle Ef 6, 4, Paedagogia Christiana, 2008, 22, 2, s. 153.

${ }^{21}$ D. Żołądź-Strzelczyk, Peregrinatio academica: studia młodzieży polskiej z Korony $i$ Litwy na akademiach i uniwersytetach niemieckich w XVI i pierwszej połowie XVII wieku, Poznań 1996, s. 40 i nn.

${ }^{22}$ M. Grzywacz, Reformacja wittenberska i szlaki jej transferu. U źródeł obecności luteranizmu w Rzeczypospolitej XVI w., [w:] Luteranizm w kulturze pierwszej Rzeczypospolitej, red. K. Meller, Warszawa 2017, s. 90-109.
} 
swobodnie agitować dla wyznania luterańskiego ${ }^{23}$. Utrzymywane były stałe kontakty poprzez regularne wysyłanie listów, często obrazujących znaczną zażyłość ${ }^{24}$. W ślad za tym szła organizacja nowej grupy wyznawców, rozkwitała także twórczość literacka. Chociaż w tym przypadku dominowały polemiki natury religijnej (dogmatycznej), zaczęły pojawiać się także interesujące teksty o charakterze parenetycznym. Część spośród nich stanowi bardzo interesujące źródło dla poznania luterańskich wartości związanych z życiem rodzinnym, a propagowanych na obszarze dawnego państwa polskiego. Poniżej zostaną zaprezentowane najciekawsze głosy w porządku chronologicznym, przede wszystkim z okresu bujnego rozkwitu literatury luterańskiej w Polsce, obrazujące z jednej strony myśl pedagogiczną, a z drugiej także praktykę (przykład pamiętnika Macieja Vorbek-Lettowa) ${ }^{25}$.

Obydwa przywołane wyżej Katechizmy luterańskie zostały wydane w języku polskim w Królewcu przez Jana Seklucjana i bardzo szybko zostały rozpowszechnione (chociaż tłumaczenia spotkały się z polemiką) ${ }^{26}$. Na szczególną uwagę zasługuje jednak dzieło, które zostało wydane jego staraniem, a którego autorem najpewniej był Stanisław Murzynowski, a mianowicie Oeconomia albo gospodarstwo. To jest nauka, jako się wszelki krześcijański człowiek w gospodarstwie sprawować ma².

Stanisław Murzynowski, jeden z bardziej prominentnych przedstawicieli polskiego ruchu luterańskiego, zasłużony tłumacz Pisma Świętego na język polski (chociaż wydanego pod nazwiskiem Jana Seklucjana), rozpoczął swoje dzieło dotyczące gospodarstwa domowego od pochwały życia rodzinnego, wierności małżeńskiej, pokornego znoszenia trudów życia codziennego i wytrwałego pozostawania przy wierze chrześcijańskiej. Rodzina, jego zdaniem, została ustanowiona $\mathrm{w}$ tym celu, aby ludzie cnotliwie się mnożyli i wychowywali swoje potomstwo ku chwale Bożej. W świetle słów Murzynowskiego, do życia rodzinnego przeznaczony został przez Boga każdy człowiek, bez względu na zajmowane stanowiska czy wykonywane zajęcia. Pojawia się tu-

${ }^{23}$ K. Mazurkiewicz, Początki Akademji Lubrańskiego w Poznaniu (1519 - 1535). Przyczynek do dziejów rozwoju nauk humanistycznych w Polsce, Poznań 1921; M. Nowicki, Vir orator czy vir probus, czyli problem recepcji antycznych wartości wychowawczych w programie wychowawczym Akademii Lubrańskiego, [w:] Ku źródtom wartości, red. P. Orlik, Poznań 2008, s. 313-326.

24 P. Matwiejczuk, Humaniści, reformatorzy, przyjaciele. Korespondencja Filipa Melanchtona do Jana Łaskiego, Rocznik Teologiczny, 2015, 57, 3, s. 347-374; por. O. Bartel, Filip Melanchton w Polsce, Odrodzenie i Reformacja w Polsce, 1961, 6.

${ }^{25} \mathrm{~W}$ niniejszym opracowaniu przedstawionych zostanie tylko kilka źródeł związanych z tą problematyką. Dzięki takiemu zabiegowi możliwe będzie dokładniejsze zaprezentowanie ich treści i dostrzeżenie specyfiki poglądów, sposobu argumentowania i swoistego klimatu życia rodzinnego. Zakładać bowiem należy, że poglądy te odzwierciedlają, przynajmniej w pewnym stopniu i w odniesieniu do niektórych rodzin, faktyczny klimat takiego codziennego życia.

26 T. Wojak, Jan Seklucjan - życie i dzieło, Rocznik Teologiczny, 1984, 26, 1, s. 85, 98 i n.

27 Tamże, s. 100, tutaj dokładniejsze informacje na temat autorstwa. 
taj bardzo czytelna idea całkowitego podporządkowania człowieka woli Bożej ${ }^{28}$, dzięki czemu ten zyskać ma wolność od cierpienia, które niosą troski życia codziennego:

będzie jemu każda praca jakoby nie praca, każda robota jakoby nie robota, bo gdy wszystko w imię boże pocznie, wielką pociechę i roskosz ma w sercu swojem i lekko każdą rzecz sprawi ${ }^{29}$.

W tym kontekście nawiązuje też do znanego motywu nowotestamentowego, w świetle którego każdy człowiek powinien pokornie nieść swój krzyż. Dodaje jednak, że nie należy w związku z tym przesadzać i wymyślać sobie dodatkowych cierpień, tylko zdać się na to, co człowiek otrzymuje od Boga ${ }^{30}$.

Według niego, nie należy koncentrować się w życiu na zdobywaniu dostatecznej żywności czy bogactwa, ale poświęcić się pracy dla zachowania pobożnego pokoju i powszechnego dobra. Temu służyć ma właśnie odpowiednie wychowanie dzieci w dobroci, posłuszeństwie, cnocie i bogobojności. Odpowiedzialność za to Murzynowski kładł na barki ojca ${ }^{31}$, ale podkreślał, że wychowanie należy również do zadań matki ${ }^{32}$, chociaż ta powinna być podporządkowana mężowi, a to ze względu na pierwszeństwo stworzenia i grzech pierworodny ${ }^{33}$. Należy zauważyć, że pogląd ten nie był charakterystyczny tylko dla luteran, w okresie staropolskim katolicy raczej w jeszcze większym stopniu wiązali kobietę z życiem rodzinnym ${ }^{34}$. Tak zarysowany obraz rodziny, zgodny w swoich podstawach z poglądami Marcina Lutra, stanowi pewnego rodzaju wzorzec rodziny luterańskiej, opartej na pewnych i stałych wartościach, i wprost, świadomie, odnoszącej się do nich.

Naczelne miejsce należało według niego do ojca rodziny (ojca czeladnego), a wynikało ono z prawa Bożego. Do zadań męża należało przede wszystkim zapewnić rodzinie i czeladzi pożywienie, bezpieczeństwo i naukę Bożą ${ }^{35}$.

28 Zob. ostatnio M.M. Kacprzak, O wolności chrześcijańskiej i niewolnej woli. Luterańska antropologia i aksjologia wobec renesansowych pytań o godność człowieka, [w:] Luteranizm w kulturze pierwszej Rzeczypospolitej, red. K. Meller, Warszawa 2017, s. 201-259.

${ }_{29}$ [S. Murzynowski], Jana Seklucyana Oeconomia albo gospodarstwo: 1546, red. Z. Celichowski, Kraków 1890, s. 19.

30 Tamże, s. 73.

31 Tamże, s. 24.

32 Tamże, s. 32.

33 Tamże, s. 34-35, 39. Dalej Murzynowski dowodzi, że ze względu na wiarę w Jezusa Chrystusa wszyscy ludzie, bez względu na pochodzenie społeczne i płeć, powinni przede wszystkim mocno trwać w prawdziwej wierze, „,czyniąc jednak każdy swemu zawołaniu dosyć wedle stanu swego" (s. 36 i n.).

34 D. Żołądź-Strzelczyk, "Jako rządzić mają rodzice córki swe". Poglądy na wychowanie kobiet w XVI-XVIII w., [w:] Rola i miejsce kobiet w edukacji i kulturze polskiej, red. W. Jamrożek, D. Żołądź-Strzelczyk, Poznań 1998, s. 58.

35 [S. Murzynowski], Jana Seklucyana Oeconomia albo gospodarstwo, s. 28. 
Autor rozpatrywanego dzieła podkreśla, że ojciec winien odkładać na bok wszelakie sprawy doczesne i całą swoją energię oraz majątek poświęcić wychowaniu dzieci w cnocie i pobożnych naukach (gruntownie) ${ }^{36}$. Warto przy tej okazji przywołać starorzymski wzorzec ojca-wychowawcy - Katona, którego osoba została wskazana przez Murzynowskiego, chociaż tylko jako poboczny wątek erudycyjny ${ }^{37}$.

Stanisław Murzynowski w sposób szczególny dostrzegał jednak trudy związane z wychowaniem potomstwa, zwłaszcza te przypisane macierzyństwu już w okresie prenatalnym („,ciężka a boleściwa rzecz jest niewieście brzemienno chodzić” ${ }^{38}$ ) i podczas porodu, którego bóle związane są z wolą Bożąa $a^{39}$ Zalecał on, by z pokorą wytrzymywać wszelakie cierpienia i oddać się w tym Bogu, gdyż wszystko dzieje się ze względu na pewien porządek i ostatecznie każdy ma obiecaną Bożą pomoc i zbawienie. Warunkiem jest pilna służba Bogu w codziennych obowiązkach, wypełniona dobrymi uczynkami i cierpliwością ${ }^{40}$, ponieważ, jak pisał Murzynowski za Listem do Tymoteusza, „niewiasty będą zbawione przez rodzenie dziatek swoich, jeśli w wierze zostaną" ${ }^{41}$.

Ma też wszelka krześciańska matka czeladna dziatki z pilnością wychować i ku służbie a bojaźni bożej, tudzież też i ku wszelkiej cnotliwości prowadzić a trzymać nauką i dobrym przykładem ${ }^{42}$.

Nauka ze strony matki powinna odbywać się prywatnie, w domu ${ }^{43}$. Tutaj zresztą koncentrowały się wszystkie ich obowiązki. Jako uzupełnienie można dodać, iż Murzynowski oczekiwał od kobiet, że będą nie tylko poddane i posłuszne swoim mężom, ale też zachowają wszelaką obyczajność i będą "łagodnego a cichego ducha”, które to cnoty uznał za najszlachetniejsze klejnoty, mogące zdobić kobietę ${ }^{44}$. Zwraca on także uwagę na to, by kobiety nie interesowały się sprawami, które nie należą od ich obowiązków oraz dbały o dobro wspólne, pochodzące z pracy męża. Zwłaszcza, by pilnie go strzegły, pożytecznie sprawowały i jego nie umniejszały ze względu na pragnienie niepotrzebnych zbytków ${ }^{45}$.

\footnotetext{
${ }^{36}$ Tamże, s. 46 i n.

37 Tamże, s. 48 i n.

38 Tamże, s. 37.

39 Tamże, s. 32.

40 Tamże, s. 31.

41 Tamże, s. 34 i n.

${ }^{42}$ Tamże, s. 32.

${ }^{3}$ Tamże, s. 34 i n.

${ }_{44}$ Tamże, s. 39.

45 Tamże, s. 43.
} 
Odrębny niejako rozdział pracy Murzynowskiego stanowią wskazówki dotyczące wychowania dzieci, problemu, jak widać, o pierwszorzędnym znaczeniu.

Napirwej, że domowe wychowanie jedno dla dziecinnego wychowania od Boga jest zrządzone i ustawione, aby były wychowany dobrze, ku czci i ku chwale naprzód panu Bogu, i tudzież też ku pocieszeniu i ku pożytku pospolitego dobra, abowiem jako z młodych cielątek wielkie krowy i woły bywają [...], tak też z dzieciństwa musimy rozumne a mądre ludzie wychować, którzyby ziemiam i ludziem mogli pożyteczni a godni być ${ }^{46}$.

Warto zwrócić uwagę na korzyści płynące z wychowania nie tylko dla najbliższej rodziny, ale też i dla "dobra pospolitego". Interesujący jest wątek wspólnotowy u Murzynowskiego, który dosyć ostrożnie się pojawia w niektórych miejscach jego dziełka. Mianowicie, z jednej strony zwraca uwagę na fakt, iż dzieci wychowywane są między innymi dla pożytku powszechnego, $z$ drugiej natomiast zaleca wychowywanie ich w poczuciu troski i wdzięczności dla Boga za wszystkie dobra powszechne, to znaczy publiczne. Wszystko oczywiście miało być realizowane poprzez służbę Bogu i w prawej bojaźni przed gniewem Bożym. Mając to na uwadze, dzieci winny w każdej sytuacji wzywać Boga, wierząc jego obietnicom i mieć na uwadze jego przykazania oraz perspektywę "srogiego sądu" ${ }^{\prime 4}$. Pomocni w tym powinni być rodzice, utrzymując dzieci w odpowiedniej karności, zwłaszcza w młodszym wieku, gdyż „młodych nałóg starszych jest uczynek" ${ }^{48}$. Podkreślał jednak, że należy zachowywać umiar w karaniu i unikać okrucieństwa, chociaż, jego zdaniem, kary cielesne są często niezbędne ${ }^{49}$.

Murzynowski bardzo zwracał uwagę na konieczność unikania próżnowania. Należało zapewnić dzieciom odpowiednie zajęcie, nie tyle dla „zapracowania" na swoje dobro $\mathrm{w}$ domu, ale ze względu na ryzyko wystąpienia u nich takich wad jak: łgarstwo, pijaństwo, skłonność do hazardu, złodziejstwa i innych negatywnych zjawisk. Autor podkreślał wyraźnie, że uwaga ta odnosi się zarówno do wychowania chłopców, jak i dziewcząt.

Podobnie jak Marcin Luter, tak i Murzynowski nakazywał posyłanie dzieci do szkoły i utrzymywanie ich w pilności nauki, przede wszystkim dla należytego zrozumienia Pisma Świętego, ale też dla pożytku powszechnego ${ }^{50}$. Przy tej okazji krytykował on współczesną sobie praktykę unikania edukacji

${ }^{46}$ Tamże, s. 44.

47 Tamże, s. 44 i n.

48 Tamże, s. 45.

49 Tamże, s. 47.

${ }^{50}$ Por. M. Luther, Do burmistrzów i rajców wszystkich miast w Niemczech, iż powinni zakładać i utrzymywać szkoty chrześcijańskie, [w:] Źródta do dziejów wychowania i myśli pedagogicznej, t. I: Od wychowania pierwotnego do końca XVIII stulecia, wydanie drugie zmienione, wyb. i oprac. S. Wo- 
szkolnej, a dbania jedynie o uzyskanie odpowiednio atrakcyjnego uposażenia w postaci kanonii czy biskupstwa. Murzynowski kierował do rodziców ważkie argumenty, przemawiające za koniecznością edukacji szkolnej, a mianowicie przygotowanie młodego umysłu do podjęcia jakiegokolwiek zajęcia w przyszłości, w tym także kaznodziejskiego ${ }^{51}$.

Dosyć zbliżone poglądy do Murzynowskiego, w kwestii wartości rodzinnych i wychowawczych, miał Erazm Gliczner Skrzetuski, jeden z najbardziej aktywnych i wszechstronnych działaczy reformacyjnych (na polu politycznym, teologicznym i pedagogicznym) ${ }^{52}$. Jego traktat pedagogiczny został opublikowany w 1558 roku, a więc zaledwie 12 lat po rozprawce Murzynowskiego. We wstępie do tego dzieła Erazm Gliczner dokonał ważnego spostrzeżenia, że człowiek, chciałoby się rzec, jest „istotą społeczną"53. Pisał mianowicie, że ludzie, "będąc $\mathrm{w}$ towarzystwie z sobą, mieli porozumienia około swego postanowienia i mięszkania na świecie", a stało się tak za sprawą woli Bożej, dzięki której także, z dwojga ludzi miało się począć potomstwo, na chwałę Bożą, cześć i sławę. Rodzice też, a zwłaszcza ojciec, powinni szczególnie troszczyć się o wychowanie dzieci, gdyż są one skarbem ojczyzny ${ }^{54}$. Wokół tych zagadnień koncentruje się problematyka traktatu.

W kontekście małżeństwa Gliczner rozważał kilka istotnych problemów, a mianowicie: dobór małżonków, płodzenie dzieci i rozkład obowiązków. Nad zagadnieniem zawarcia małżeństwa młodych ludzi, według Glicznera, w zasadzie powinni czuwać rodzice, biorąc pod uwagę kilka istotnych spraw. Jako wiek odpowiedni dla tego Gliczner przyjął za Arystotelesem dla kobiety 18 lat, dla mężczyzny natomiast $36^{55}$. Dodał jednak od siebie uwagę, że w sytuacji młodych mężczyzn, jeśliby zauważalne było ryzyko wchodzenia przez nich w nieprawe związki ze względu na cielesne popędy, ojciec, zgodnie z nauką św. Pawła, powinien pomyśleć o ożenku odpowiednio wcześniej ${ }^{56}$. Autor

łoszyn, Kielce 1995, s. 299 i n., który wiązał edukację szkolną z potrzebami prywatnymi i publicznymi.

51 [S. Murzynowski], Jana Seklucyana Oeconomia albo gospodarstwo, s. 45 i n.

52 E. Gliczner Skrzetuski, Ksią̇ki o wychowaniu dzieci barzo dobre, pożyteczne i potrzebne, z których rodzicy ku wychowaniu dzieci swych naukę dołożna wyczerpnać moga, red. W. Wisłocki, Kraków 1876; por. A. Danysz, Erazm Gliczner jako pedagog. Studyum nad pierwsza pedagogika polska, Roczniki Towarzystwa Przyjaciół Nauk Poznańskiego, 1911, 38, s. 3 i n.; A. Krawczyk, Rola rodziny, religii i społeczeństwa w wychowaniu człowieka wedtug Erazma Glicznera, [w:] Z dziejów polskiej kultury i oświaty od średniowiecza do początków XX wieku, red. K. Jakubiak, T. Maliszewski, Kraków 2010, s. $459-478$.

${ }^{53}$ Oczywiście zagadnienie to, mające swoje źródło jeszcze w pismach Arystotelesa, stało się powszechne na gruncie pedagogiki chrześcijańskiej, ostatnio na ten temat: B. Kiereś, Personalistyczny wymiar wspólnotowego życia w rodzinie. Kontekst cywilizacyjny, Paedagogia Christiana, 2015, 36, 2, s. 195-208.

${ }^{54}$ E. Gliczner Skrzetuski, Książki o wychowaniu dzieci, s. 3 i n.

55 Tamże, s. 129.

${ }^{56}$ Tamże, s. 130 i n. 
zwrócił także uwagę na pochodzenie społeczne małżonków, twierdząc, że nierówność w tych kwestiach może rodzić rozmaite problemy ${ }^{57}$. Zdecydowanie więcej uwagi poświęcił on jednak sprawom moralnym, co ciekawe jednak, tylko w odniesieniu do kandydatki na małżonkę. W jego opinii, powinna się ona charakteryzować nieskazitelną opinią, cnotą, statecznością i brakiem sławy czy rozgłosu wśród „rymotwórców” ${ }^{58}$. Ważne miejsce w tym zajmuje oczywiście także czystość cielesna, przeciwstawiona nierządowi ${ }^{59}$. W kwestiach urody zauważył, że ma to drugorzędne znaczenie, aczkolwiek zgodnie z obiegową opinią (co podkreślał), brzydota nieodłącznie jest związana ze złem. Najlepszym rozwiązaniem zatem jest połączenie urody z cnotą: „dobra a cnotliwa żona wielkie jest ochędożeństwo małżonka każdego" ${ }^{60}$. Na pierwszym miejscu jednak postawił on bojaźń Bożą, rozumianą w ten sposób, iż Bóg winien zawsze być przedmiotem rozważań i celem wszelakiego działania. „Zaprawdę, niemasz nic lepszego małżonkowi po żenie swej poznawać, jedno samo nabożeństwo: kiedy ona o Boga będzie dbała, w słowie sie Bożem kochała, często sie Bogu modliła, a jemu samemu służyła"61. Interesujące jest, iż od doboru małżonki Gliczner w znacznym stopniu uzależniał życie religijne całej rodziny. Rodzina może żyć w pełni szczęścia wówczas, "gdy małżonkowie sie sami między sobą dobrze rządzą, poćciwie sie obchodzą, a w bojaźni Bożej mięszkają, a w tem gdy sie dodrze [!] mają, na niedostatek nie skarżą" 62 .

Niebagatelne znaczenie dla życia rodzinnego miało posiadanie potomstwa, co jest według Glicznera wolą Bożą, ale potomstwa z prawego łoża. Wielką wartością dla niego była wierność małżeńska, której poświęcił całkiem sporo miejsca w swojej rozprawie. Warto tutaj zauważyć tylko, że w świetle jego opinii, owoc współżycia pozamałżeńskiego, czyli dziecko z nieprawego łoża, oprócz wykluczenia społecznego, oczekiwać powinno także pewnego rodzaju odrzucenia przez Boga (,płód nieprawy (...) u Boga mało co miejsca ma”, ,takowe dzieci (...), są przed Panem Bogiem jako błoto a wszelaka nieczystość" $)^{63}$.

Zrodzone dzieci powinny stać się przedmiotem bardzo starannego wychowania, któremu Gliczner poświęcił najwięcej uwagi, a które powinno być przepełnione miłością (co jest naturalne w rodzinie, jak zauważył) ${ }^{64}$ i trwać

\footnotetext{
57 Tamże, s. 132.

58 Tamże, s. 7.

59 Tamże, s. 134.

60 Tamże, s. 132-133, 137.

61 Tamże, s. 134.

62 Tamże, s. 138.

${ }^{63}$ Tamże, s. 11-14.

${ }^{64}$ Tamże, s. 56, dodaje też: „Ta miłość tedy nie z okrucieństwa, nie z żadnej furyej, nie z hańbienia wyrastać ma, ale z takiego umysłu, któryby pomagał obojej stronie, i ojcowi i synowi".
} 
nieustannie aż do śmierci rodziców ${ }^{65}$. Tutaj jednak, ze względu na charakter pracy, skupimy się tylko na niektórych kwestiach. Nadrzędnym celem wychowawczym jest przygotować dzieci do odnalezienia „królestwa niebieskiego a sprawiedliwości Bożej", inne wartości mają znaczenie drugorzędne ${ }^{66}$. Co ciekawe, stwierdzenie to można uzupełnić też ważną uwagą z dalszej części traktatu, mianowicie:

Pamiętać na to mają [rodzice - M.N.], iż nie na rozkosz Pan Bóg człowieka chciał mieć, ale na cnotę ku poznaniu Bóstwa swego, aby człowiek dobry żywot wiódł, a jego znał i miłował, na co sie snadź mieć nie będzie, jeźli za noworosłych lat fundamentu jakiego ku temu sobie nie zamierzy a nie założ ${ }^{67}$.

Żałować trzeba, iż ten wątek filozoficzno-teologiczny nie został dokładniej przedstawiony, ponieważ nie był zbyt często podejmowany w literaturze typowo pedagogicznej tego czasu. Także Stanisław Murzynowski w omawianym dziele kwestie epistemologiczne całkowicie przemilczał. U Erazma Glicznera Skrzetuskiego natomiast dopatrywać się możemy wpływów nurtu devotio moderna, odchodzącego od religijnego formalizmu i dążącego do zwrócenia się człowieka do własnego wnętrza, gdzie należało szukać poznania.

Widzimy więc, że do zadań rodziców będzie należało przygotowanie tego właśnie fundamentu, który pozwoli dziecku w przyszłości osiągnąć poznanie Boga i, w domyśle, doznać szczęścia. Realizacja tego postulatu miała się odbywać na kilka sposobów: poprzez zapewnienie dziecku chrztu ${ }^{68}$, odpowiedni przykład, pilnowanie pobożności oraz utrzymywanie karności. Rodzice więc powinni mieć dbałość zarówno o swoją mowę, jak i czyny. „Bo cóż inszego jest dziecię zgorszyć, jedno mu z siebie zły przykład a pochop dać, aby też tego naśladowało, coby u nas albo usłyszało albo ujrzało" ${ }^{69}$.

Rodzice winni zatem dawać dzieciom dobry przykład, zwłaszcza w najmłodszym okresie, gdyż „w czem się nałoży dziecię z młodu, w tem zatwardnieje zawżdy, tak że go trudno będzie w więtszych leciech naprawić”. Oprócz tego powinni też odpowiednio wyważyć metody wychowawcze tak, aby poprzez „wielkie kochanie a pieszczenie” nie „zepsuć” dziecka, ale też zbyt wielką karnością nie wyrządzić jakiejś szkody („,bezmierne a zapamiętliwe karanie więcej gorszy i kazi, niż pomaga" ${ }^{70}$. Chowanie dziecka w nadmiernych rozkoszach, wśród nieustających delicji i folgowaniu własnej woli może, zdaniem Glicznera, wyrządzić mu wiele szkody. Za dobry wzór stawia on

\footnotetext{
65 Tamże, s. 139.

66 Tamże, s. 25 i n.

67 Tamże, s. 41.

68 Tamże, s. 25.

69 Tamże, s. 32 i n.

70 Tamże, s. 38-42, 53.
} 
wychowanie u „dobrego" ziemiaństwa, gdzie „synowie u ojców swych ani dosypiają, ani też nazbyt sobie rozkoszują". Do dobrego wychowania wystarczy skromny ubiór (któremu zresztą autor poświęca wiele uwagi) i zapewnienie odpowiedniego zajęcia, dzięki któremu może wyrosnąć z młodzieńca człowiek ",biegły i ćwiczony ${ }^{71 "}$. Syn powinien więc ćwiczyć się w godnych obowiązkach, które podobają się Bogu, i których młody człowiek by się nie wstydził przed innymi ludźmi ${ }^{72}$. Odpowiednim zajęciem dla dziecka jest, w jego mniemaniu, nauka w szkole, której poświęcił wiele uwagi, posiłkując się poglądami na przykład Kwintyliana, podkreślając przy tym, że obowiązkiem rodziców, a zwłaszcza ojca, jest zadbanie o odpowiedniego nauczyciela i dozór nad postępami w nauce ${ }^{73}$. Dla osiągnięcia dobrego efektu wychowawczego dzieci powinny także przywyknąć do „mierności a stateczności i szczyrości" i unikać rzeczy, zwróconych ku światu zewnętrznemu. Ważne jest, by nie pozwolić dziecku wyrastać w uczuciu pychy i swawoli. Wymaga się od niego także obyczajności ${ }^{74}$. Wizję dobrze wychowanego człowieka najlepiej zresztą przedstawiają słowa samego autora:

My żeśmy się uczyli, a czas na naukach niemały nałożyli i strawili, nie dla czego inszego to w nas było, jedno abyśmy wżdam ku jakiemu kresowi przybieżeli, z nauką sie naszą między inszymi popisali, czyniąc to dla pospólnego pożytku: naprzód, aby Pan Bóg był w rodzaju ludzkim poznan, czcion, ważon i chwalon; rzecz pospolita krześciańska przez nas była zapomożona i podpierana; naostatek ojczyźnie, rodzicom, przyjacielom, krewnym, powinowatym i inszym ludziom wspołek, żebyśmy sie dobrze, pocześnie postawili, z nas aby im słowo dobre i pociecha dobra urosła ${ }^{75}$.

Dwa przedstawione powyżej teksty, wzajemnie się uzupełniające, dają już całkiem spore wyobrażenie na temat luterańskich wartości rodzinnych, krzewionych na terenach ówczesnego państwa polskiego. Obraz ten warto jeszcze uzupełnić jednym interesującym głosem, mianowicie Marcina Kwiatkowskiego, zaprezentowanym w dziele Książeczki rozkoszne [...] o poćciwym wychowaniu..., a wydanym "nakładem ubogim” w 1564 roku, w celu uzyskania posady nauczyciela księcia pruskiego Albrechta Fryderyka. Zauważyć można, że te trzy rozprawki pojawiły się w zbliżonym czasie, i to w momencie wzmożonej aktywności protestanckiej na terenie Rzeczypospolitej, co daje nam doskonałe możliwości poznawcze. Warto jeszcze podkreślić, że dzieło ogłoszone przez Kwiatkowskiego nie jest jego oryginalnym osiągnięciem, a jedynie tłumaczeniem niezmiernie popularnego i docenianego powszechnie

\footnotetext{
71 Tamże, s. 47.

72 Tamże, s. 43.

73 Tamże, s. 61-119.

74 Tamże, s. 50.

75 Tamże, s. 119.
} 
dzieła Piotra Pawła Wergeriusza (Starszego) ${ }^{76}$. Stąd też ograniczymy się tutaj do uwypuklenia tylko najważniejszych kwestii.

Wergeriusz w pierwszym miejscu omawiał wychowanie dzieci wysokiego pochodzenia społecznego, podkreślając, że aby korzystać z przypadających im w udziale godności, powinni „nazacniejsze a naznamienitsze wszystki postępki z siebie pokazować" i wyćwiczyć się w najprzedniejszych naukach ${ }^{77}$. Nie należy zważać na przyziemne wartości, jak bogactwa, chwała, piękność, uroda, przyjaciele, rozkosze, ale starać się o "owoc cnót”, który trwa wiekuiście. „Abowiem zawżdy ma być wzgląd na cnotę i ku zacnym sprawom ma być napięty umysł, a o żywot niewiele się mamy starać" 78 .

Dla osiągnięcia takiego celu, z jednej strony młodzieniec winien obrać sobie jednego lub więcej doświadczonych mężów, których mógłby naśladować w obyczajach i cnotach, z drugiej zaś „starsi” winni stanowić przykład „statecznej powagi"79. Opiekunowie powinni ustrzec dziecko przed możliwością występku. Jednym z przykładów jest chociażby unikanie kłamstwa poprzez maksymalne ograniczanie możliwości wypowiadania się młodzieńca ${ }^{80}$. Umysł jego powinno się przyzwyczajać do cierpliwości, a ciało do rycerstwa, żeby przez "ukurzenie piaskiem” i pot przyzwyczajał się do pracy ${ }^{81}$. Przykładem do naśladowania miałby być w świetle tej pracy ojciec Ubertyn, do którego autor kierował dzieło, napisane w formie listu. Otóż ojciec ten miał w szczególny sposób wychwalać cierpliwość w pracy i własnym przykładem to potwierdzać, nie zważając przy tym na "ciążkość ciała swego" ${ }^{2}$. Nieco uwagi poświęcono także ubiorowi, który powinien być odpowiedni dla stanu człowieka, "poczciwy” i nie „nazbyt przesadzony" 83 .

Dużą wartość przypisywał Wergeriusz edukacji szkolnej w dziedzinie sztuk wyzwolonych, czyli nauk godnych człowieka wolnego, skutkujących w pierwszej kolejności cnotą, a dalej czcią i chwałą. Dowodził, iż należy ją rozpoczynać od najwcześniejszych lat, gdy umysł jest najchłonniejszy, a kontynuować także w "starych leciech" ${ }^{\prime 4}$. Zdobyte w ten sposób wykształcenie

${ }^{76}$ M. Kwiatkowski, Marcina Kwiatkowskiego Ksiażeczki rozkoszne o poczciwem wychowaniu dziatek 1564 i Wszystkiej Lifflanckiej Ziemi opisanie 1567, red. Z. Celichowski, Kraków 1889 [cytuję według wydania z 1889, por. też M. Kwiatkowski, Pisma: edycje królewieckie 1564-1577, red. M. Pawlak, Bydgoszcz 1997].

77 Tamże, s. 15.

78 Tamże, s. 59.

79 Tamże, s. 20 i n.

${ }^{80}$ Tamże, s. 22 i n.

${ }^{81}$ Tamże, s. 57 i n.

82 Tamże, s. 59.

83 Tamże, s. 72.

${ }^{84}$ Tamże, s. 31. Por. K. Ratajczak, Vergerio Piotr Pawet Starszy, [w:] Encyklopedia pedagogiczna XXI wieku, t. VII V-Ż, red. T. Pilch, Warszawa 2008, s. 7 i n. Tam dalsza literatura. 
należało wykorzystywać nie tylko dla własnego dobra, ale także dla dobra powszechnego (Rzeczypospolitej) $)^{85}$.

Niewielkie to dziełko daje nam ciekawą wskazówkę, dotyczącą luterańskiego spojrzenia na problematykę rodziny i wychowania. Otóż, należy mieć świadomość, że tłumaczenie tego traktatu na język polski nie mogło być przypadkowe i w oczach Marcina Kwiatkowskiego musiało uchodzić za przydatne i zgodne z wartościami przez niego wyznawanymi. Widzimy zatem, podobnie jak u Erazma Glicznera, ogromną wagę, przypisywaną kształceniu w sztukach wyzwolonych, zwłaszcza wiarę w skuteczność edukacji dla osiągnięcia szczęścia jednostkowego, rodzinnego i powszechnego. W utworze tym widoczne jest także przekonanie o przeważającej wartości wychowania dziecka w najwcześniejszym okresie jego życia, stąd też największa odpowiedzialność spoczywa każdorazowo na barkach rodziców, a zwłaszcza ojca. Warto w tym kontekście odnieść się więc do bezpośredniej relacji takiego ojca, związanego z prezentowanymi wartościami, dzięki czemu można będzie dokonać próby oceny stopnia realizacji postulowanych wartości w życiu codziennym.

Możliwość takową daje nam wyjątkowa spuścizna po Macieju z rodu Vorbek-Lettow, w postaci jego „Skarbnicy pamięci”, spisywanej w XVII wie$\mathrm{ku}^{86}$. Autor tego dzieła pochodził z niezbyt zamożnej szlachty, ale ojciec zaplanował dla niego karierę lekarską, stąd otrzymał on gruntowne wykształcenie, które rozpoczęło się nauką w szkole przy wileńskim zborze luterańskim. Związki Lettowa z wyznaniem luterańskim były silne. W starszym wieku stał się dość aktywnym działaczem na tym polu.

W tekście od samego początku uderza szczególna rola ojca autora. Z jednej strony, co całkowicie dla pamiętnikarza jest oczywiste, decydował on o losie syna, powierzając go nauce odpowiednim nauczycielom i wysyłając na studia zagraniczne, z drugiej zaś cieszył się wielkim szacunkiem syna, który z perspektywy czasu zwie go „rodzicem miłym” i "rodzicem dobrodziejem”, chociaż ten potrafił w ostrych słowach go karcić i zmieniać synowskie postanowienia ${ }^{88}$. Odnotować także należy charakterystyczne dla ducha pobożności luterańskiej poddanie woli Bożej i uznanie całkowitej odeń zależności.

Co dobrze uważając, wziąwszy Pana Boga na pomoc, który mną samym, pamięcią i wszystkim, co z szczerej łaski i szczodrobliwości Boskiej ręki mam, podług woli i upodobania swego władnie i kieruje ${ }^{89}$.

${ }^{85}$ Tamże, s. 35.

${ }^{86}$ M. Vorbek-Lettow, Skarbnica pamięci: pamiętnik lekarza króla Wtadystawa IV, Wrocław-Warszawa 2006.

87 Tamże, s. 13, 15.

88 Tamże, s. 29 i n.

${ }^{89}$ Tamże, s. 23. 
Wiara w prowidencję boską widoczna jest na kartach całego pamiętnika, zwłaszcza w odniesieniu do sytuacji zagrożenia albo wdzięczności. Takich zaś nie brakowało w życiu autora.

Ojciec Macieja Lettowa (w przeciwieństwie do dziadka) wiele uwagi poświęcał edukacji szkolnej syna, bezpośrednio interesował się nauczycielami i programem szkolnym, dbał też o czystość języka polskiego syna (spostrzegłszy pewne problemy $\mathrm{w}$ tym względzie, wynikłe $\mathrm{z}$ długiego przebywania w środowisku niemieckim, nakazał synowi powrót do Wilna), czuwał wreszcie bardzo pieczołowicie nad jego edukacją religijną ${ }^{90}$.

Życie rodzinne Lettowa, w świetle jego wspomnień, można uznać za wzorowe dla rodziny luterańskiej. Zawarcie małżeństwa bardzo szybko zaowocowało licznym potomstwem, a wspólne życie przepełnione było bojaźnią Bożą (na co wskazuje np. wypadek małżonki Macieja w browarze, uznany przez niego za karę za własne grzechy), pobożnością (w odniesieniu do nowo narodzonego dziecka: „aby rósł na chwałę Jego świętą" ${ }^{91}$ ) i cierpliwym oddaniem pracy (już jako nowożeniec, łamiąc obyczaje, Maciej Lettow podążył za swoim protektorem na wyprawę jako medyk obozowy, w kolejnych okresach tylko krótko przebywając $\mathrm{w}$ domu $\left.{ }^{92}\right)$.

Bardzo wyraźna w pamiętniku jest miłość Macieja do swojej rodziny i ogromne do niej przywiązanie. Z wielkim szacunkiem, oddaniem, miłością i wdzięcznością wypowiadał się o swoich rodzicach. O własnej żonie, dzieciach i wnukach wypowiadał się w sposób stateczny i spokojny, ale przepojony troską i miłością. W tekście widać wiele tego przykładów przy informacjach o narodzinach dzieci, ich chorobach, czy śmierci. Ta, w odniesieniu do jego dzieci czy wnuków, pojawiała się dosyć często. Kiedy zmarł jego syn Władysław, pisał: „z niewypowiedzianym żalem moim w Warszawie z tego ziemskiego błotnego padołu do przybytków wiekuistych przeniesion jest", a wkrótce po tym, po śmierci wnuka Władysława: „broń nas Chryste Jezu w przyszły czas od podobnego smętku i żalu" ${ }^{\prime \prime 3}$.

W kolejnym roku, jak opisuje to Lettow, miał miejsce podczas wspólnej podróży rodziny Lettowów z dworem królewskim pożar w ich gospodzie, podczas którego zaginęli jego dwaj synowie, wskutek czego małżonka autora płakała i "łamała sobie ręce, pod zamkowym murem leżąc”, on sam zaś tak o sobie pisał: ,ja sobie lamentuję, jak nieswój tam i sam po zamku padam, dziatek szukam". Po ich szczęśliwym odnalezieniu odnotował natomiast: „O jaka tam była radość, kiedyśwa ich zdrowych oglądali!". Lettow zresztą

\footnotetext{
90 Tamże, s. 31 i n.

91 Tamże, s. 140.

92 Tamże, s. 63 i n.

93 Tamże, s. 142 i n.
} 
utracił w tym pożarze znaczną część swojego dobytku i dokumentów, gdyż „zaraz wszystkich rzeczy odżałowawszy” ratował małżonkę i dzieci („maluczkie synaczki moje" $)^{94}$.

Zdaje się, że uwagi te wystarczająco dobrze ukazują, że wartości opisywane w teorii znajdowały odzwierciedlenie także w praktyce życia codziennego. Pamiętać jednak należy, że ukazują one wartości uniwersalne dla kultury chrześcijańskiej, nie tylko protestanckiej.

Podsumowując powyższe rozważania i prezentację, można ostrożnie wyodrębnić kilka cech specyficznych dla poglądów protestanckich. Będzie to przede wszystkim bardzo mocno podkreślana bojaźń Boża, rozumiana dosłownie i raczej różna od „zwykłej” pobożności, która jest oczywiście cechą charakterystyczną wychowania w ogóle w epoce staropolskiej ${ }^{95}$. Po drugie, w tekstach luterańskich bardzo silnie podkreślana jest rola ojca w wychowaniu nie tylko dzieci, ale wręcz całej rodziny, wraz z przynależną czeladzią (na wzór tradycji rzymskiej). Ojciec uznany został w rodzinie za swoistego zastępcę Boga, jego pełnomocnika, posiadającego bardzo szerokie kompetencje, ale też podlegającego licznym obwarowaniom. Pokreślić jednak wypada, że wyżej analizowani autorzy silnie wskazywali na znaczącą rolę matki w wychowaniu i utrzymaniu całej rodziny, od której zaangażowania i roztropności zależy dobro wszystkich jej członków. Pamiętać zaś należy, że o doniosłej roli kobiety w rodzinie rzadko pamiętali staropolscy teoretycy wychowania i to w zasadzie przy okazji jej funkcji macierzyńskiej, w okresie niezbędnej opieki nad dziećmi ${ }^{96}$.

Szczególne znaczenie przypisywano samej rodzinie, jako instytucji ustanowionej przez Boga. Z powyższych tekstów jasno wynika, że małżonków powinno się dobierać w sposób pieczołowity i uwzględniać wolę młodych ludzi. Związek powinien być przepełniony miłością, wzajemnym oddaniem, szczerością i zaufaniem oraz uczciwością. Bardzo łatwo zestawić to z uderzającym zepsuciem obyczajów, zwłaszcza w odniesieniu do warstwy magnackiej, gdyż tam było to najwyraźniej zauważalne ${ }^{97}$. Zadaniem, przy którym małżonkowie mieli się łączyć w staraniach, było przede wszystkim wychowanie potomstwa w wyznawanych wartościach. Warto zauważyć, że założenia

94 Tamże, s. 148-150.

95 Por. uwagi dotyczące postulatów wychowawczych Jana Firleja, D. Żołądź-Strzelczyk, Dziecko w dawnej Polsce, Poznań 2002, s. 212.

96 Tamże, s. 198-200; por. D. Żołądź-Strzelczyk, Rola matki w opiece nad dzieckiem w nowożytnej myśli i praktyce pedagogicznej, [w:] Polskie dziedzictwo edukacyjne od XVI do XX wieku - ciagłość i zmiana. Zbiór studiów i rozpraw ofiarowanych Profesorowi Lechowi Mokrzeckiemu z okazji Jubileuszu 80 urodzin, red. R. Grzybowski i in., Toruń 2015, s. 324-337.

97 W. Czapliński, J. Długosz, Życie codzienne magnaterii polskiej w XVII wieku, Warszawa 1982, s. 33-38. 
te kontrastują z częstym w renesansie obrazem rodziny, opartej na zasadach ekonomicznych, chociaż pamiętać trzeba, że nie brakowało wówczas także i związków romantycznych, obrazujących doskonałą przyjaźń małżonków ${ }^{98}$.

Niewątpliwą zasługą teoretyków luterańskiego wychowania było upowszechnienie poglądów antycznych i wczesnochrześcijańskich, podkreślających wartość rodzicielstwa i potrzebę pieczołowitego wychowania potomstwa, osobiste zaangażowanie obojga rodziców w pracę wychowawczą i staranie o edukację swoich dzieci. Pamiętać bowiem należy, że o ile poglądy te były sporadycznie głoszone we wcześniejszej historii wychowania, tak nie zauważamy ich poważniejszej recepcji. Luteranizm, jak się zdaje, przyniósł tutaj pewne korzystne zmiany, spowodowane w dużym stopniu wykorzystaniem języka ojczystego.

\section{BIBLIOGRAFIA}

Axer J., Kultura polska z punktu widzenia mechanizmów recepcji tradycji antycznej. Prolegomena do syntezy, [w:] Humanistyczne modele kultury nowożytnej wobec dziedzictwa starożytnego, red. M. Prejs, Warszawa 2010.

Bartel O., Filip Melanchton w Polsce, Odrodzenie i Reformacja w Polsce, 1961, 6.

Barycz H., Andrzej Maksymilian Fredro wobec zagadnień wychowawczych, Archiwum do Dziejów Oświaty i Wychowania, 1948, 6.

Budzyński J., Paideia humanistyczna, czyli wychowanie do kultury. Studium z dziejów klasycznej edukacji w gimnazjach XVI-XVIII wieku (na przykładzie Śląska), Częstochowa 2003.

Czapliński W., Długosz J., Życie codzienne magnaterii polskiej w XVII wieku, Warszawa 1982.

Danysz A., Erazm Gliczner jako pedagog. Studyum nad pierwsza pedagogika polska, Roczniki Towarzystwa Przyjaciół Nauk Poznańskiego, 1911, 38.

Delumeau J., Cywilizacja Odrodzenia, Warszawa 1987.

Delumeau J., Roche D., Historia ojców i ojcostwa, przekł. J. Radożycki, M. Radożycka-Paoletti, Warszawa 1995.

Gliczner Skrzetuski E., Ksiażki o wychowaniu dzieci barzo dobre, pożyteczne i potrzebne, z których rodzicy ku wychowaniu dzieci swych naukę dotożna wyczerpnać moga, red. W. Wisłocki, Kraków 1876.

Grzywacz M., Reformacja wittenberska i szlaki jej transferu. U źródeł obecności luteranizmu w Rzeczypospolitej XVI w., [w:] Luteranizm w kulturze pierwszej Rzeczypospolitej, red. K. Meller, Warszawa 2017.

Kacprzak M.M., O wolności chrześcijańskiej i niewolnej woli. Luterańska antropologia i aksjologia wobec renesansowych pytań o godność człowieka, [w:] Luteranizm w kulturze pierwszej Rzeczypospolitej, red. K. Meller, Warszawa 2017.

Kaczorowski W., Wychowanie Janusza Radziwitła w świetle instrukcji rodzicielskiej, Sprawozdania. Opolskie Towarzystwo Przyjaciół Nauk, Wydział I Nauk Historyczno-Społecznych, 1984, 19.

Kiereś B., Personalistyczny wymiar wspólnotowego życia w rodzinie. Kontekst cywilizacyjny, Paedagogia Christiana, 2015, 36, 2.

${ }_{98}$ M.L. King, Kobieta, [w:] Człowiek renesansu, red. E. Garin, przekł. A. Osmólska-Mętrak, Warszawa 2001, s. 283-337. 
King M.L., Kobieta, [w:] Człowiek renesansu, red. E. Garin, przekł. A. Osmólska-Mętrak, Warszawa 2001.

Krawczyk A., Rola rodziny, religii i społeczeństwa w wychowaniu człowieka wedtug Erazma Glicznera, [w:] Z dziejów polskiej kultury i oświaty od średniowiecza do początków XX wieku, red. K. Jakubiak, T. Maliszewski, Kraków 2010.

Kułaczkowski J., Wskazania wychowawcze dla ojców w świetle Ef 6, 4, Paedagogia Christiana, $2008,22,2$.

Kwiatkowski M., Pisma: edycje królewieckie 1564-1577, red. M. Pawlak, Bydgoszcz 1997.

Kwiatkowski M., Marcina Kwiatkowskiego Ksiażeczki rozkoszne o poczciwem wychowaniu dziatek 1564 i Wszystkiej Lifflanckiej Ziemi opisanie 1567, red. Z. Celichowski, Kraków 1889.

Luther M., Do burmistrzów i rajców wszystkich miast w Niemczech, iż powinni zakładać i utrzymywać szkoty chrześcijańskie, [w:] Źródła do dziejów wychowania i myśli pedagogicznej, t. I: Od wychowania pierwotnego do końca XVIII stulecia, wydanie drugie zmienione, wyb. i oprac. S. Wołoszyn, Kielce 1995.

Luther M., Pisma etyczne, red. M. Hintz, Bielsko-Biała 2009.

Luther M., Wantuła A., Luter, Mały Katechizm, Duży Katechizm, Bielsko-Biała 2000.

Mazurkiewicz K., Początki Akademji Lubrańskiego w Poznaniu (1519 - 1535). Przyczynek do dziejów rozwoju nauk humanistycznych w Polsce, Poznań 1921.

Meller K., Luterańskie novum w kulturze polskiej XVI w., [w:] Luteranizm w kulturze pierwszej Rzeczypospolitej, red. K. Meller, Warszawa 2017.

Milerski B., O pedagogicznych poglądach Marcina Lutra, Myśl Protestancka, 1998, 1.

Milerski B., Pedagogiczne dziedzictwo protestantyzmu, Gdański Rocznik Ewangelicki, 2012, 6.

[Murzynowski S.], Jana Seklucyana Oeconomia albo gospodarstwo: 1546, red. Z. Celichowski, Kraków 1890.

Nowicki M., Vir orator czy vir probus, czyli problem recepcji antycznych wartości wychowawczych w programie wychowawczym Akademii Lubrańskiego, [w:] Ku źródłom wartości, red. P. Orlik, Poznań 2008.

Ojcowskie synom przestrogi. Instrukcje rodzicielskie (XVI-XVII w.), oprac. i wstępem opatrzyły D. Żołądź-Strzelczyk, M.E. Kowalczyk, Wrocław 2017.

Podzielny J., Cele związku matżeńskiego wedtug Marcina Lutra, Roczniki Teologii Ekumenicznej, 2010, 57, 2.

Przestrogi i nauki dla dzieci. Instrukcje rodzicielskie (XVIII w.), oprac. i wstępem opatrzyły M.E. Kowalczyk, D. Żołądź-Strzelczyk, Wrocław 2017.

Ratajczak K., Vergerio Piotr Pawet Starszy, [w:] Encyklopedia pedagogiczna XXI wieku, t. VII $V-\dot{Z}$, red. T. Pilch, Warszawa 2008.

Sakowicz E., Wychowanie młodego pokolenia w religii biblijnego Izraela, Paedagogia Christiana, 2011, 27, 1.

Sokołowski W., Studia i peregrynacje Janusza i Krzysztofa Radziwiłłów w latach 1595-1603 (Model edukacji syna magnackiego na przełomie XVI i XVII wieku), Rozprawy z Dziejów Oświaty, 1992, 35.

Swoboda A., Ojcostwo Boże i ojcostwo ludzkie w ujęciu św. Augustyna, Vox Patrum, 2015, 63, 35.

Śledzianowski J., Autorytet rodzicielski w Rodzinie Nazaretańskiej i dzisiaj, Paedagogia Christiana, 2011, 27.

Turek W., Godność ciata ludzkiego wedtug Tertuliana. Analiza komentarzy do tekstów Rdz 1, 26-27; 2, 8; 1Kor 3, 16, Vox Patrum, 2015, 63, 35.

Vorbek-Lettow M., Skarbnica pamięci: pamiętnik lekarza króla Wtadysława IV, Wrocław - Warszawa 2006.

Warmiński I., Andrzej Samuel i Jan Seklucjan, Poznań 1906. 
Wojak T., Jan Seklucjan - życie i dzieło, Rocznik Teologiczny, 1984, 26, 1.

Żołądź-Strzelczyk D., Peregrinatio academica: studia młodzieży polskiej z Korony i Litwy na akademiach $i$ uniwersytetach niemieckich w XVI i pierwszej połowie XVII wieku, Poznań 1996.

Żołądź-Strzelczyk D., "Jako rządzić mają rodzice córki swe". Poglądy na wychowanie kobiet w XVI-XVIII w., [w:] Rola i miejsce kobiet w edukacji i kulturze polskiej, red. W. Jamrożek, D. Żołądź-Strzelczyk, Poznań 1998.

Żołądź-Strzelczyk D., Dziecko w dawnej Polsce, Poznań 2002.

Żołądź-Strzelczyk D., Rola matki w opiece nad dzieckiem w nowożytnej myśli i praktyce pedagogicznej, [w:] Polskie dziedzictwo edukacyjne od XVI do XX wieku - ciagłość i zmiana. Zbiór studiów i rozpraw ofiarowanych Profesorowi Lechowi Mokrzeckiemu z okazji Jubileuszu 80 urodzin, red. R. Grzybowski i in., Torun 2015.

Żołądź-Strzelczyk D., "Pod każdym względem szlachetne ci daję wychowanie”. Studia z dziejów wychowania szlachty w epoce staropolskiej, Wrocław 2017. 